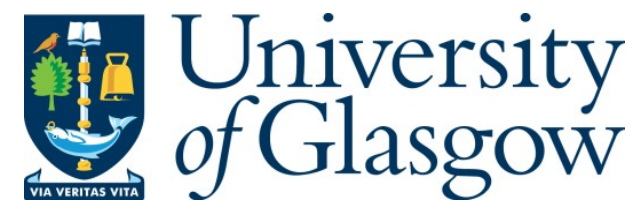

Curl, Angela, and Davison, Lisa (2014) Transport geography: perspectives upon entering an accomplished research sub-discipline. Journal of Transport Geography, 38. pp. 100-105. ISSN 0966-6923

Copyright (C) 2014 Elsevier Ltd.

A copy can be downloaded for personal non-commercial research or study, without prior permission or charge

Content must not be changed in any way or reproduced in any format or medium without the formal permission of the copyright holder(s)

When referring to this work, full bibliographic details must be given

http://eprints.gla.ac.uk/94726

Deposited on: 26 June 2014

Enlighten - Research publications by members of the University of Glasgow http://eprints.gla.ac.uk 


\title{
Transport Geography: Perspectives upon entering an accomplished research sub-discipline
}

\author{
Angela Curl, University of Glasgow \& Lisa Davison, University of Ulster
}

\section{Introduction}

The Royal Geographical Society (with the Institute of British Geographers) 2012 Annual Conference provided a landmark for UK Transport Geography, being 40 years since the Transport Geography Research Groups group's inauguration in 1972. As highlighted by Preston and O'Connor, (2008) in the most recent book on the subject (Knowles et al. 2008), Transport Geography was initially aligned with the quantitative revolution in human geography and has since adopted more pluralistic methodologies, with more critical approaches informing the 'new mobilities paradigm'. During the previous 40 years these developments were reflected in a book series, an international journal and through representation at the RGS-IBG annual conference. The 2012 conference provided an opportunity to celebrate these successes as well as the opportunity to explore the future of an established research group.

This viewpoint considers our experience as researchers entering an accomplished research subdiscipline. In presenting this we interpret discussions from the workshop 'Imagining the next 40 years of Transport Geography' that was co-organised by the authors. We also recognise the influence of other experiences of being Transport Geographers and refer to this and the wider literature, concentrating on the Journal of Transport Geography but also recognising a range of dissemination avenues used within the sub-discipline. In this viewpoint we consider some challenges for the field of Transport Geography over the next 40 years.

\section{Workshop: Imagining the next 40 years of Transport Geography}

We designed the workshop session to encompass a general discussion around topical areas for emerging research, followed by small group discussions centred on the four themes:

- Transport Geography in the wider geography context;

- Methodological challenges within Transport Geography;

- Application of Transport Geography to policy and practice; and

- Transport Geography in taught courses.

These themes developed from an early career session held at the 2011 conference organised by TGRG and AK-Verkehr (the transport working group of the German Association of Geography). We sought to bring issues raised by early career researchers into discussion during a session which engaged both established academics and those new to the field.

Group discussions were facilitated by the authors of this piece alongside Peter Jones and Derek Hall. The themes were discussed by each group in turn, with the possibility to add to arguments and comments from the previous group or groups. Participants were invited to comment on a summary report after the event. Participants were mainly employed in the UK but some had academic experience outside the UK. Therefore, although a range of nationalities and age groups were represented, we acknowledge that the viewpoints presented here relate distinctly to Transport Geography as it has developed in the United Kingdom, but the broad themes are of relevance to Transport Geographers globally. Our viewpoint also demonstrates the epistemological differences 
within the Transport Geography community, considering both the workshop participants and the broader community.

The remainder of the viewpoint is structured as follows: first we explore the discussion themes; then we highlight the topical challenges for the next 40 years, concluding with a précis of each.

\section{Identifying the 'geography' in Transport Geography}

Transport Geography is at the interface between geography and transport studies, with many interdisciplinary connections. For example, academics involved in Transport Geography research are situated within, or move between, a range of disciplinary areas: they may be based in civil engineering, geography, mathematics, economics, sociology and psychology amongst others. This leads to the question of what is distinctly geographical about Transport Geography with respect to transport and travel behaviour research in the broadest sense. This was seen by some as a branding problem, with Transport Geography as a discipline being in some cases inseparable from transport studies more broadly, and seen as peripheral to critical human geography in most departments. This also raises questions as to whether being 'Transport Geographer' is an identity in its own right or whether members of the research group have other aliases.

Whilst the concept of scale is contested within human geography (e.g. Marston et al. 2002 and in contrast Jonas, 2006) the scale of issues emerged as an important theme throughout the workshop. It can be argued, given the importance of context, that geographers study transport issues at a range of, often overlapping scales, ranging from the individual (e.g. Delbosc \& Currie, 2011.; Kamruzzaman, Hine, Gunay, \& Blair, 2011), household (e.g. Buliung \& Kanaroglou 2006; Fox 1995; McDonald 2008), neighbourhood (e.g. Mitra \& Buliung 2012; Grengs 2010), city (e.g. Banister 2011; Hesse 2013), region (e.g. Reggiani et al. 2011; Thomas \& O'Donoghue 2013), state (e.g. Sismanidou et al. 2013; Russo \& Musolino 2012) to the global (e.g. Grubesic et al. 2009; Tavasszy et al. 2011; Liu et al. 2013). Participants also identified a potential role for the supra-global.

Within geography, it is often perceived that the adoption of more critical approaches has come later in Transport Geography than other human geographies and Transport Geography has at the same time maintained its quantitative core. This leads to associations with positivism and critiques of Transport Geography as remaining in the past (Goetz et al, 2009, Røe, 2000; Hall, 2004; Hanson, 2008) and not following the epistemological trends in human geography, as result becoming being marginalised (Vowles 2006). Such critiques have given rise to parallel streams of work within geography such as Social Justice (Farrington \& Farrington 2005; Lucas 2006) and Mobilities (Shaw \& Hesse 2010; Sheller \& Urry 2006; Cass et al. 2005) Despite researching within the remit of Transport Geography, those engaged in these parallel streams may not necessarily consider themselves Transport Geographers, perhaps because of its perceived associations with positivism and a desire to be different. However, there are signs that this is changing, for instance, through the co-sponsoring of RGS-IBG conference sessions leading to a broader range of geographers engaging with Transport Geography.

Opportunities for Transport Geography as a sub-discipline relate to the openness of geography as a whole and its capability to adapt and function within multidisciplinary spheres. Discussions identified a range of possibilities where both more traditional applied and novel theoretical approaches can develop geographical understanding without needing to be recognised as falling under the remit of specific disciplines. This relates to the suggestion by Preston and O'Connor (2008) that Transport Geography forms part of an interdisciplinary approach and Goetz et al.'s (2009) point that transport is 
the focus of a much broader range of geographical work than might initially be assumed, including, but not limited to migration, housing mobilities, environmental behaviours and health.

There is evidence that Transport Geography research is represented on other transport fora, for example through the travel behaviours network and The Forge young researcher's network which brought together transport researchers working in a range of disciplines. This interdisciplinarity is encouraging but raises the question again about what is distinctly geographical and what separates the work of Transport Geographers from transport researchers involved in other networks. For some authors (e.g. Vowles, 2006) this is not problematic: given that geography is at the core of transport, there is no need to distinguish the geographical from the study of transport. We would argue that it is the ability of geographers to be critical, in drawing attention to inequalities, ethical and social issues, which distinguishes Transport Geography from transport studies more broadly, but there is no clear divide.

\section{Is Transport Geography really synonymous with quantitative methods?}

We included this topic of discussion in the workshop in response to the description of Transport Geography as synonymous with quantitative methods (Gregory et al. 2009) in the Dictionary of Human Geography. The roots of the sub-discipline in a positivist worldview mean that quantitative methods are built into the fabric of Transport Geography. This was recognised by some participants who maintained that quantitative methods were 'core' to Transport Geography, providing a 'springboard' for supplementary qualitative approaches 'where appropriate'.

Participants valued novel quantitative approaches to understanding Transport Geography. The growing role of technology, in particular the GPS capabilities of mobile devices, was recognised as providing new sources of understanding mobility (Beecham \& Wood 2013; Shoval et al. 2010; Shen et al. 2013; Devlin et al. 2008). Though this development raises issues around data security, ownership and access and ethics of use (Cottrill \& Thakuriah 2011, Wilson, 2013) and presents further methodological and computational challenges to respond to new data sources, extending to the role of data mining (O'Brien et al. 2013). Such methodological advances offer potential to better understand existing research questions and the questions which arise over the next 40 years, for example by combining large scale datasets. Transport Geographers play an important role in understanding the role of technology, noting that a (quantitative) critical geographical approach is essential to such an area of study given the potential ethical issues arising.

Considering epistemological developments over the last 40 years, a number of participants held the view that qualitative methods should continue to have a growing role in Transport Geography. Qualitative approaches encompass, but are not limited to, the use of a single approach to data collection, such as in-depth interviews to appreciate the nuances in practice and policy (Aldred \& Jungniekel, 2014; Beirão \& Cabral, 2007; Curl, et al. 2012) or in exploring the lived experience of travel through autobiographical experience (Jain, 2011), from public records of travel (Budd, 2011) or from walk-along interviews (Evans \& Jones, 2011). Other Transport Geography research has used a range of qualitative methods to build understanding (Clayton and Musselthwaite, 2013; Pooley et al., 2011).

Whilst dichotomising approaches methodologically as quantitative/positivist and qualitative/critical oversimplifies this trend there was also the argument that Transport Geography should further embrace research with stronger theoretical underpinnings, drawing on a wider range of disciplines. A current example of which is research examining socio-technical transitions in transport, which, as 
discussed by Geels (2012), moves away from the neo-classicist and engineering approaches predominant in transport research considering the broader context, where understanding focuses upon systemic change. Specifically, workshop attendees expressed concern regarding a 'false dichotomy' between the qualitative and the quantitative, advocating a mixed method approaches as discussed by authors including Zolnik (2009) and Książkiewicz (2012). In order to achieve this researchers need to further acknowledge the roles and 'complementarity' of quantitative and qualitative approaches and an ability to 'articulate the relationship' between them (e.g. Davison \& Knowles, 2006; Kwan \& Schwanen, 2009; Porter et al., 2013). Given the audience and the authors, this could be a justification for the status quo, but it is a stance also supported by a benchmarking review which looks beyond UK geography (ESRC, 2013). This emphasises the roles of quantitative methods and geographical information systems (GIS) across human geography sub-disciplines. And, as highlighted by Kwan and Knigge (2006), GIS whilst often considered to involve more quantitative methods is also of value to qualitative research.

\section{The application of Transport Geography to policy and practice}

The applied nature of Transport Geography and the relevance to policy and practice were recognised as strengths within the community. The desire or requirement to be policy relevant has a core influence upon methodological approaches often convincing Transport Geographers to provide quantifiable evidence in order to drive decisions, with elements which can be monetised viewed as being more 'robust' (DfT, 2013). This is perhaps more persuasive than encouraging social and cultural approaches to permeate the sub-discipline. Yet this led to a poignant question from a workshop participant:

"Are we politically captured by the status quo? Is trying to be politically relevant making us geographically irrelevant?"

This desire to be politically and policy relevant can be evidenced by publication. Of 1606 articles in the Journal of Transport Geography available through Science Direct (September 2013), 1331 (83\%) are returned from an 'all fields' search for policy, suggesting at least a perceived if not real impact on policy. Though at present there is a barrier between academic knowledge transmitted through journals and practice. A mechanism for increasing access to academic knowledge is to provide 'open access' journal articles, and there are compelling reasons for Transport Geographers to engage, providing data sensitivity is considered. There is also evidence that researchers in the field of Transport Geography do make an active contribution to policies and practices through work completed on a consultative basis (Lucas, 2011); research dissemination (Aldred et al. 2013; Newton, 2013, TRAVELPLANPLUS, 2012); publishing books of immediate relevance (Docherty \& Shaw, 2008); and contributing to understanding and knowledge through other channels (e.g. Goodwin, 2011). This is despite a decrease in governmental investment in transport-related research, a prominent impact being the closure of the UK Transport Research Centre.

From another standpoint there has been an increasing emphasis from funding bodies for applicants to identify the 'impact' of their research, moving the responsibility from government to researchers (European Commission, 2011; Research Councils UK, 2011). Given the human and policy aspects of Transport Geography, the importance of impact is not as novel as the funding bodies would suggest, indeed many participants discussed their links with practice and there is evidence that action research provides potential to learn through the application of policy and practice, as demonstrated by, e.g. Preston et al. 2011 in a session at the RGS conference. In recognising the human focus of Transport Geography research, participants highlighted the importance of the wider dissemination of research 
findings. The media and social media were recognised as avenues for dissemination. On one hand this addressed concerns regarding how information can be communicated to non-academics in a timely manner but raised concerns about the 'dumbing down' of academic work.

Maintaining political relevance can be challenging, even when researchers act within the existing structures. Participants identified a tension between the short term political system and the need for a longer term view to provide a solid evidence base, which leads to incompatibility in the temporal scales of institutions. But arguably the main challenge is to question the current practices of government, thereby increasing the value of the diversity of Transport Geography research across a range of audiences. Recently, the TGRG has engaged directly with policy makers through workshop sessions attached to the RGS-IBG Annual Conference, held with Scottish Government in 2012 and the Department for Transport (DfT) in 2013, though in doing this it is important that a dialogue is created rather than a monologue.

\section{Communicating transport to geography students}

The multi-disciplinary nature of Transport Geography was also recognised with respect to teaching. As a result of the spatial nature of transport and travel, and the structures and systems in place that enable such mobility, 'Transport Geography' is taught across a range of degree programmes, for instance transport planning, town planning or civil engineering. Yet, as recognised by both lecturers on current geography courses and previous scholars of geography at undergraduate level, the term 'Transport Geography' may not feature within a geography degree programme as there may not be the perceived space for a dedicated transport module. However, often concepts are absorbed in a range of other modules, such as those related to social, cultural or economic geography.

Given the focus on and enthusiasm for research under the auspices of Transport Geography a virtuous circle of research-led teaching and teaching-led research was identified as playing a positive role in programme and module design. Participants reflected that Transport Geography as module in an undergraduate degree would be best placed in the second year where the application of a subject is required and where existing knowledge from the first year can be drawn upon. In terms of content such a module is likely to provide an overarching view rather than delving into detail. Its position within human geography was identified as somewhat contradictory given the perceived demand for quantitative skills required at postgraduate level. In many cases, unless there is a specialist research interest, Transport Geography may only receive detailed attention at the Masters level, particularly with respect to quantitative methods.

Participants highlighted that opportunities to communicate Transport Geography to students need to trickle down, not only into university-based taught courses, but also into pre-university geography. In practical terms this involves inclusion of core concepts in standard text books, not only benefitting Transport Geography but also providing an accurate context for other elements of geography. Undergraduate, and to an extent postgraduate programmes, need to embrace the inclusion of quantitative methods with application to human geography thus benefiting both graduates and employers. Examples were discussed, including discussion of the limited availability of programmes combining of BA (Human) Geography with BSc Mathematics. Although there is a much greater emphasis on quantitative skills within physical geography and many students will study both, it is their application in human geography which is often missing, when there is no reason why human geography cannot be both critical and quantitative (Goetz et al, 2009). Within this debate some participants suggested that the focus should be on quantitative skills as qualitative skills are easier to learn if required at postgraduate level, perhaps signifying that a quantitative bias remained amongst 
some Transport Geographers, and that there is a need to emphasise the importance of theoreticallygrounded qualitative research for the discipline.

Some participants argued that there is greater potential to recognise the Transport Geography in existing modules, or indeed build the geography of transport and travel into other modules, for instance through GIS. It was suggested that the TGRG could facilitate this is through a textbook to provide a core text to complement existing Transport Geography books. This has been actualised following a discussion at the TGRG meeting at the 2012 conference (Barr et al. forthcoming). Where research meets teaching there is greater need to share Transport Geography research in a range of journals to highlight the interdisciplinary nature of Transport Geography and thus broaden its appeal.

\section{Challenges for the next 40 years}

We have identified a number of challenges for exploration over the next 40 years, relating to the fabric of Transport Geography and to 'doing' Transport Geography (or being a Transport Geographer) and our workshop discussions points emphasised the importance of epistemological viewpoint with respect to each. It is interesting that the workshops revealed a perceived lack of development of critical Transport Geography. We have reflected upon how this has been influenced by the participants involved their approach to discussing the essence of Transport Geography. We argue that whilst many participants were open to the multi-faceted approaches in Transport Geography there were also representative who either held a more 'traditional' view or were keen for the Transport Geography community to draw more on a wider range of approaches. We are of the view that approaches from the positivist and quantitative to the more critical, drawing on social theory, are encompassed within what is Transport Geography. Efforts should be made to reflect this more widely in journal articles, topical books and through the geography curriculum, given the perceived lack of critical Transport Geography by some of our workshop participants. Re-naming the research group to reflect and incorporate mobilities research in addition to what might traditionally be viewed as Transport Geography could help to further reflect the breadth of diversity of the sub-discipline.

In the remainder of this section we review the topical challenges for Transport Geography, as the methodological considerations are discussed in detail above. The issues discussed during the workshop session suggest a level of consensus with the dictionary definition of Transport Geography:

"A branch of human geography concerned with: transport policy practice and analysis, especially the impacts of deregulation, privatization, and subsidy control; infrastructure impact on trip-making, the spatial economy, and regional development; technological innovation in transport and telecommunications and global and regional economic integration; the growing mobility gap between rich and poor and differential accessibility to jobs and services; transport, environment, and energy; travel, recreation, and tourism; and spatial and behavioural aspects of modelling transport demand."

(Mayhew, 2009)

Indeed geography as a discipline is well placed to take the holistic view, bringing together research expertise from a range of backgrounds and epistemological stances. We do not cover all issues of relevance to Transport Geography here, but instead draw on a few examples which highlight the breadth of the sub-discipline with reference to topics of concern to workshop discussants. In reviewing these we make brief reference to work undertaken under these topics, the scales at which they predominate and make a judgement upon the durability of such issues for Transport Geographers. 
While the specific foci of research may shift with political, economic and social trends, we identify overarching themes, based on the topics discussed at the workshop, which we expect to guide Transport Geography research in the coming decades. These relate to reliance on fossil fuel and climate change, socio-technical change, social impacts, health and wellbeing and issues of equity and justice.

Globally, reliance on fossil fuel was recognised in relation to the environmental impact of climate change (Chapman 2007). Though what may be judged to be the precise focus of the community fluctuates, for instance the prominence of peak oil in and implications upon fuel security and the longevity of existing systems and structures featured in Transport Geography sessions at the RGSIBG conference (Jones, 2012, Knowles, 2012), yet since then the research focus has reduced given arguments for technological advancements and questions as to the accuracy of forecasts (Chapman, 2014). The resilience of transport systems in response to extreme weather events within this context was identified as of increasing concern across a range of scales (e.g. www.disruptionproject.net; Guiver 2012) and continues to be of research interest. At a more localised level participants paid particular attention to the social impacts, should systems which support livelihoods fail (Lucas \& Pangbourne, 2012). It is interesting that there was limited consideration by participants as to the impacts of local air quality having synergies with health geography given the 'co-benefits' of transport-related policies and practices as discussed by e.g. Giles-Corti et al, 2010; Creutzig \& He, 2009; Younger et al, 2008. Over the next 40 years, whilst the emphasis will continue to change in response to current knowledge and judgements, the resource requirements allowing for movements in time and space will continue to be a focus for Transport Geography critiques, as will the vulnerability of existing systems.

In addition to the methodological contribution of technology already discussed, socio-technical change was highlighted as important, for example in transitioning to a low carbon economy. A techno-centric perspective on reducing the impact of transport and travel upon climate change and altering resource demand focuses on the role of technology in allowing for alternative fuels for propulsion (e.g. Anandarajah, 2013) and increased fuel efficiency. Technology demonstrates wider potential to make travel more efficient, affecting personal and freight transport (Golob \& Regan 2001; Hesse \& Rodrigue 2004); Information Technology can assist with making journeys by both private and public transport (Line et al. 2011) and can also be used as a valuable source of information as individuals and groups travel through time and space (Velaga et al. 2012) as well as influencing travel behaviours (Tang \& Thakuriah 2012) and potentially reducing the need to travel (Kenyon et al. 2003). In taking a multi-level perspective, drawing from approaches from other disciplines not often applied to transport, Geels (2012) argues that green propulsion modes and ICT/ITS has the most momentum and are therefore better placed to take advantage of 'windows of opportunity' when compared to other policy interventions, including those encouraging use of other modes and changes in lifestyle. Such publications and the emphasis upon technology and ICT/ITS from research funders would suggest that this will remain a topical area of interest to the community over time.

The final topical research area centres around issues of justice and equity. Geographers have long been concerned with issues such as equality of access and an ability to participate in everyday life and access essential services across populations (Farrington \& Farrington, 2005; Farrington, 2007; Lucas, 2006; Preston \& Rajé, 2007) and the impacts of transport. Despite this there is a need for greater theoretical consideration of what constitutes an equitable transport system (Martens \& Golob, 2012). Related to this participants identified a need to develop alternative approaches to understanding (dis)benefits of transport for the individual, related to happiness and quality of life as opposed to solely economic growth and increased consumption (Carse 2011; Kolodinsky et al. 2013; DfT, 2011; 
Lucas et al. 2009) Nordbakke and Schwanen, 2014). This is particularly true in understanding the mobility of older people (e.g. Nordbakke \& Schwanen, 2014).and given increased focus on the health impacts of transport interventions (e.g. Johnson \& Margolis, 2013).

Regarding the discussion on identifying the geography in Transport Geography, we would argue that it is the ability of geographers to be critical, in drawing attention to inequalities, ethical and social issues, which distinguishes Transport Geography from transport studies more broadly, but that of course there is not a clear divide. So whilst reliance upon a finite resources and socio-technical changes are core themes access and inequalities in transport remain an overarching theme, relevant at all scales and of particular concern given broader societal issues such as the current economic climate and an ageing population. Understanding the social and spatial inequalities arising from policy decisions can be a key contribution of geographers to transport studies. There is arguably a need to take a more holistic view of issues such as equity and accessibility, rather than viewing them as solely transport issues, meaning that geographers are well placed to study these issues across a range of subfields.

Whilst in 1972 the developments within the sub-discipline could not be foreseen, particularly relating to the epistemological developments over time and the ways in which Transport Geography has distinguished itself with respect to disciplines outside geography and geography sub-disciplines, Transport Geography has proven applications ranging from the disaggregate level to more aggregate levels which links to the range of spatial scales of interest to Transport Geographers. Over the next 40 years we expect developments in geographical understanding of transport from the individual level to the supra-global. The main topical issues that are expected to be influential in the next decade stem from a reliance upon finite resources, given current rates of consumption, and the individual to global impacts of this environmentally and socially. Participants emphasised the human response, with consideration for behavioural change and socio-technical transitions. Access and inequalities in transport were an overarching theme, relevant at all scales and of particular concern given broader societal issues such as the current economic climate and an ageing population. We expect methodological challenges too, notably in relation to technological development and use of 'big data' sources, of which we should be critical (Lovelace, 2014). These discussions gave rise to a range of potential issues and future directions for geographical research in transport and mobilities and we are under no doubt that uncertainties and opportunities exist in the future of the discipline.

\section{Acknowledgements}

We thank the participants in the workshop and hope they will see this as an accurate reflection of the ideas discussed at the session. We would also like to thank two anonymous referees, whose comments have substantially developed this paper.

\section{REFERENCES}

Aldred, R \& Jungnickel, K., 2014 Why culture matters for transport policy: the case of cycling in the UK, Journal of Transport Geography, 34, 78-87

Aldred, R., Banister, D., Chalabi Z., Lloyd, S., Macmillan, A., Schwanen, T. \& Woodcock, J., Modelling on the Move: Towards transport system transitions? Available: http://modellingonthemove.org/ [Accessed 08/01/2014] 
Anandarajah, G., McDowall, W., \& Ekins, P. (2013) Decarbonising road transport with hydrogen and electricity: Long term global technology learning scenarios, International Journal of Hydrogen Energy,3(8), 3419-3432

Banister, D., 2011. Cities, mobility and climate change. Journal of Transport Geography, 19(6), pp.1538-1546.

Barr, S; Prillwitz; J., Ryley T. \& Shaw, G. (forthcoming) Geographies of Transport and Mobility Ashgate, Farnham

Beecham, R. \& Wood, J., 2013. Exploring gendered cycling behaviours within a large-scale behavioural data-set. Transportation Planning and Technology, pp.1-15.

Beirão, G. \& Cabral J.A. S., 2007. Understanding attitudes towards public transport and private car: A qualitative study, Transport Policy, 14(6), 478-489,

Budd, L.C.S., 2011. On being aeromobile: airline passengers and the affective experiences of flight, Journal of Transport Geography, 19(5), 1010-1016,

Buliung, R.N. \& Kanaroglou, P.S., 2006. A GIS toolkit for exploring geographies of household activity/travel behavior. Journal of Transport Geography,, 14(1), pp.35-51.

Carse, A., 2011. Assessment of transport quality of life as an alternative transport appraisal technique. Journal of Transport Geography, 19(5).

Cass, N., Shove, E. \& Urry, J., 2005. Social exclusion, mobility and access. The Sociological review, 53(3), pp.539-555.

Chapman, L., 2007. Transport and climate change: a review. Journal of Transport Geography, 15(5), pp.354-367.

Chapman, I., 2014. The end of Peak Oil? Why this topic is still relevant despite recent denials, Energy Policy, Volume 64, Pages 93-101, ISSN 0301-4215, http://dx.doi.org/10.1016/j.enpol.2013.05.010.

Clayton, W. \& Musselwhite, C., 2013. Exploring changes to cycle infrastructure to improve the experience of cycling for families.Journal of Transport Geography, 33. pp. 54-61. ISSN 09666923

Cottrill, C. \& Thakuriah, P. , 2011. Protecting Location Privacy. Transportation Research Record: Journal of the Transportation Research Board, 2215.

Creutzig, F., \& He, D., 2009. Climate change mitigation and co-benefits of feasible transport demand policies in Beijing. Transportation Research Part D: Transport and Environment, 14(2), 120 131. doi:10.1016/j.trd.2008.11.007

Curl, A., Nelson, J. D., \& Anable, J., 2011. Does Accessibility Planning address what matters? A review of current practice and practitioner perspectives. Research in Transportation Business \& Management, 2, 3-11.

Davison, L., \& Knowles, R.D., 2006. Bus quality partnerships, modal shift and traffic decongestion. Journal of Transport Geography, 14 (3). pp. 177-194. 
Delbosc, A. \& Currie, G., 2011. Transport problems that matter - social and psychological links to transport disadvantage. Journal of Transport Geography, 19(1).

Devlin, G.J., McDonnell, K. \& Ward, S., 2008. Timber haulage routing in Ireland: an analysis using GIS and GPS. Journal of Transport Geography, 16(1), pp.63-72.

DfT, 2011. Detailed Guidance on Social and Distributional Impacts of Transport Interventions TAG Unit 3.17. Available at: http://www.dft.gov.uk/webtag/documents/expert/pdf/unit3.17.pdf [Accessed January 12, 2012].

DfT (2013) TAG UNIT A1.1 Cost-Benefit Analysis, October 2013 (Available:

https://www.gov.uk/government/uploads/system/uploads/attachment_data/file/254266/webtag-tag-unit-a11-cost-benefit-analysis.pdf accessed 08/01/14)

Docherty, I., \& Shaw, J., 2008. Traffic Jam: 10 Years of 'Sustainable' Transport in the UK. Policy Press, Bristol. ISBN 978184742072532

ESRC (2013) International Benchmarking Review of UK Human Geography (Available http://www.esrc.ac.uk/_images/Human-Geography-Benchmarking-ReviewReport tcm8-25257.pdf accessed 18th December 2013)

European Commission, 2011. Commission Staff Working Paper Impact Assessment (Available: http://ec.europa.eu/research/horizon2020/pdf/proposals/horizon_2020_impact_assessment_report.pdf\#vie $\underline{\mathrm{w}}=$ fit\&pagemode $=$ none accessed $08 / 01 / 14$ )

Evans, J. \& Jones, P., 2011. The walking interview: Methodology, mobility and place, Applied Geography, 31(2), 849-858

Farrington, J. \& Farrington, C., 2005. Rural accessibility, social inclusion and social justice: towards conceptualisation. Journal of Transport Geography, 13(1), pp.1-12.

Farrington, J.H., 2007. The new narrative of accessibility: its potential contribution to discourses in (transport) geography. Journal of Transport Geography,, 15(5), pp.319-330.

Fox, M., 1995. Transport planning and the human activity approach. Journal of Transport Geography,, 3(2), pp.105-116.

Geels, F. W., 2012 A socio-technical analysis of low-carbon transitions: introducing the multi-level perspective into transport studies, Journal of Transport Geography, 24, Pages 471-482, ISSN 09666923, http://dx.doi.org/10.1016/j.jtrangeo.2012.01.021.

Giles-Corti, B., Foster, S., Shilton, T., \& Falconer, R., 2010. The co-benefits for health of investing in active transportation. New South Wales Public Health Bulletin, 21(5-6), 122-7.

doi:10.1071/NB10027

Goetz, A., Vowles, T., \& Tierney, S., 2009. Bridging the Qualitative-Quantitative Divide in Transport Geography, The Professional Geographer, 61(3), 323-335

Golob, T.F. \& Regan, A.C., 2001. Impacts of information technology on personal travel and commercial vehicle operations: research challenges and opportunities. Transportation Research Part C: Emerging Technologies, 9(2), pp.87-121. 
Goodwin, P., 2011. Local transport today 2004-2011. London, UK: Landor.

Gregory, D., Johnston, R., Pratt, G., Watts, M., \& Whatmore, S., 2009. The Dictionary of Human Geography, $\left(5^{\text {th }}\right.$ ed $)$ Chichester, Wiley-Blackwell

Grengs, J., 2010. Job accessibility and the modal mismatch in Detroit. Journal of Transport Geography, 18(1).

Grubesic, T.H., Matisziw, T.C. \& Zook, M.A., 2009. Spatio-temporal fluctuations in the global airport hierarchies. Journal of Transport Geography, 17(4), pp.264-275.

Guiver, J., 2012. Travel Disruption: Three Case Studies, Available at: http://www.disruptionproject.net/wp-content/uploads/2013/01/Jo-Guiver-2012-TravelDisruption_Three-Case-Studies2.pdf.

Hall, D., 2006. Towards a gendered transport geography, Journal of Transport Geography, 12(3), 245-247

Hanson, S., 2003. Transportation: hooked on speed, eyeing sustainability. In E. Sheppard \& T. Barnes (Eds.), A Companion to Economic Geography. Malden, MA: BLACKWELL PUBLISHING.

Hesse, M., 2013. Cities and flows: re-asserting a relationship as fundamental as it is delicate. Journal of Transport Geography, 29, pp.33-42.

Hesse, M. \& Rodrigue, J.-P., 2004. The transport geography of logistics and freight distribution. Journal of Transport Geography, 12(3), pp.171-184.

Jain, J., 2011. The classy coach commute. Journal of Transport Geography, 19 (5). pp. 1017-1022.

Jonas, A. E. G., 2006. Pro scale: further reflections on the 'scale debate' in human geography. Transactions of the Institute of British Geographers, 31: 399-406. doi: 10.1111/j.1475-

5661.2006.00210.x

Jones, P., 2012. Transport Geography: 40.40 vision, Research in Transport Geography: the next 40 years, RGS-IBG Annual International Conference, Edinburgh, July, 2012

Kamruzzaman, M., Hine, J., Gunay, B. \& Blair, N., 2011. Using GIS to visualise and evaluate student travel behaviour. Journal of Transport Geography, 19(1), pp.13-32.

Kenyon, S., Rafferty, J. \& Lyons, G., 2003. Social Exclusion and Transport in the UK: A Role for Virtual Accessibility in the Alleviation of Mobility-Related Social Exclusion? Journal of Social Policy, 32(3), pp.317-338.

Knowles R.D., Shaw J. \& Docherty I. (Eds), 2008. Transport Geographies: Mobilities, Flows and Spaces, Blackwell Publishing, Oxford

Knowles, R., 2012 Transport shaping space before and after Peak Oil, Hoyle Lecture in Transport Geography, RGS-IBG Annual International Conference, Edinburgh, July, 2012

Kolodinsky, J.M. DeSisto, T.P., Propen, D., Putnam, M.E., Roche, \& E. Sawyer, W.R.,.., 2013. It is not how far you go, it is whether you can get there: modeling the effects of mobility on quality of life in rural New England. Journal of Transport Geography, 31, pp.113-122. 
Książkiewicz, S..2012. Quantitative or qualitative transport planning ? An interdisciplinary geographic perspective. Prace Geograficzne 11/2012; 130:131-139.

DOI:10.4467/20833113PG.12.024.0665

Kwan, M-P. \& Knigge L., 2006. Doing qualitative research using GIS: An oxymoronic endeavor? Environment and Planning A, 38(11): 1999-2002.Kwan, M-P and Schwanen, T. (2009). Quantitative revolution 2: The critical (re)turn. The Professional Geographer, 61(3): 283-291.

Line, T., Jain, J. \& Lyons, G., 2011. The role of ICTs in everyday mobile lives. Journal of Transport Geography, 19(6), pp.1490-1499.

Liu, X., Derudder, B. \& García, C.G., 2013. Exploring the co-evolution of the geographies of air transport aviation and corporate networks. Journal of Transport Geography, 30, pp.26-36.

Lovelace, R., 2014. 'Can social media data be useful in Spatial Modelling? A case study of 'museum tweets' and visitor flows'. presented at GISRUK2014, Glasgow, April 2014. Slides available: https://speakerdeck.com/robinlovelace/social-media-and-big-data-in-spatial-modelling

Lucas, K., 2006. Providing transport for social inclusion within a framework for environmental justice in the UK. Transportation Research Part A: Policy and Practice, , 40(10), pp.801-809.

Lucas, K., Tyler, S. \& Christodoulou, G., 2009. Assessing the "value" of new transport initiatives in deprived neighbourhoods in the UK. Transport Policy, 16(3).

Lucas, K., 2011. Merseytravel Neighbourhood Travel Teams Evaluation Report Report for Merseytravel Public Transport Authority

Lucas, K. \& Pangbourne, K., 2012. Transport and climate change policy in the United Kingdom: a social justice perspective. Chapter 11 in, Ryley, T. and L. Chapman (eds.) Transport and Climate Change. Emerald. pp. 287-312. ISBN: 9781780524405.

Marston, S. A., Jones, J. P. \& Woodward, K., 2005. Human geography without scale. Transactions of the Institute of British Geographers, 30: 416-432. doi: 10.1111/j.1475-5661.2005.00180.x

Martens, K., \& Golob, A., 2012. A justice-theoretic exploration of accessibility measures. in Geurs, K., Krizek, K J. \& Reggiani, A. Accessibility Analysis and Transport Planning: Challenges for Europe and North America. NECTAR Series on Transportation and Communications Networks Research. Edward Elgar. Cheltenham, UK; Northampton, MA, USA/.

Mayhew, S., 2009. Transport Geography. in A Dictionary of Geography. Oxford, University Press

McDonald, N.C., 2008. Household interactions and children's school travel: the effect of parental work patterns on walking and biking to school. Journal of Transport Geography,, 16(5), pp.324-331.

Mitra, R. \& Buliung, R.N., 2012. Built environment correlates of active school transportation: neighbourhood and the modifiable areal unit problem. Journal of Transport Geography, 20, pp.51-61.

Newton, R., 2013. DSOPM004: Pedestrian Crossings (Available http://www.idgo.ac.uk/pdf/PedestrianCrossings.pdf accessed 23/12/13) 
Nordbakke, S. \& Schwanen, T., 2014. Wellbeing and mobility: a theoretical framework and literature review focusing on older people. Mobilities, 9(1): 104-129.

O’Brien, O., Cheshire, J. \& Batty, M., 2013. Mining bicycle sharing data for generating insights into sustainable transport systems. Journal of Transport Geography.

Pooley, C.G., Horton, D., Scheldeman, G., Tight, M., Jones, T., Chisholm, A., Harwatt, H.,\& Jopson, A., 2011. Household decision-making for everyday travel: a case study of walking and cycling in Lancaster (UK), Journal of Transport Geography, 19(6), 1601-1607

Porter, G., Tewodros, A., Bifandimu, F., Gorman, M., Heslop, A., Sibale, E., Awadh, A., \& Kiswaga, L., 2013. Transport and mobility constraints in an aging population: health and livelihood implications in rural Tanzania, Journal of Transport Geography, 30, 161-169

Preston, J. \& Rajé, F., 2007. Accessibility, mobility and transport-related social exclusion. Journal of Transport Geography,, 15(3), pp.151-160.

Preston J., \& O'Connor K., 2008, Revitalized transport geographies, [in:] Transport geographies: Mobilities, flows and spaces, (ed.) r. Knowles, J. Shaw and I. Docherty, Blackwell, oxford, 227-37

Preston, J., Oglivie, D. \& Brand C., 2011. Measuring and Evaluating Physical Measures to Promote Walking and Cycling: The iConnect Baseline Surveys, New perspectives on walking and cycling, RGSIBG Annual International Conference, London, August, 2011

Reggiani, A. Bucci, P., Russo, G., Haas, A. \& Nijkamp, P.., 2011. Regional labour markets and job accessibility in City Network systems in Germany. Journal of Transport Geography, 19(4), pp.528-536.

Research Councils UK, 2011. RCUK Typology of Research Impacts (Available:http://www.rcuk.ac.uk/documents/impacts/TypologyofResearchImpacts.pdf, accessed 08/01/14)

Røe, P-G., 2000. Qualitative research on intra-urban travel: an alternative approach, Journal of Transport Geography 8(2), 99-106,

Russo, F. \& Musolino, G., 2012. A unifying modelling framework to simulate the Spatial Economic Transport Interaction process at urban and national scales. Journal of Transport Geography, 24, pp.189-197.

Schwanen, T., Banister, D., \& Anable, G,. 2012. Rethinking habits and their role in behaviour change: the case of low-carbon mobility, Journal of Transport Geography 24, 522-532

Shaw, J. \& Hesse, M., 2010. Transport, geography and the "new" mobilities. Transactions of the Institute of British Geographers, 35(3), pp.305-312.

Sheller, M. \& Urry, J., 2006. The new mobilities paradigm. Environment and Planning - Part A, 38(2), pp.207-226.

Shen, Y., Kwan, M.-P. \& Chai, Y., 2013. Investigating commuting flexibility with GPS data and 3D geovisualization: a case study of Beijing, China. Journal of Transport Geography, 32, pp.1-11. 
Shoval, N. Auslander, G., Shalom, K.C., Isaacson, M., Landau, R. \& Heinik, J.1., 2010. What can we learn about the mobility of the elderly in the GPS era? Journal of Transport Geography, 18(5), pp.603-612.

Sismanidou, A. Tarradellas, J. Bel, G. \& Fageda, X., 2013. Estimating potential long-haul air passenger traffic in national networks containing two or more dominant cities. Journal of Transport Geography, 26, pp.108-116.

Tang, L. \& Thakuriah, P. (Vonu), 2012. Ridership effects of real-time bus information system: A case study in the City of Chicago. Transportation Research Part C: Emerging Technologies, 22, pp.146-161.

Tavasszy, L. Minderhoud, M. Perrin, J-F., \& Notteboom T.,., 2011. A strategic network choice model for global container flows: specification, estimation and application. Journal of Transport Geography, 19(6), pp.1163-1172.

Thomas, P. \& O’Donoghue, D., 2013. The Channel Tunnel: transport patterns and regional impacts. Journal of Transport Geography, 31, pp.104-112.

TRAVELPLANPLUS (2012), How to create and sustain a Local Travel Plan Network (Available:http://www.travelplanplus.eu/project results.php\#7, accessed 23/12/13)

Velaga, N.R. Beecroft, M. Nelson, J.D. Corsar, D. \& Edwards P.,, 2012. Transport poverty meets the digital divide: accessibility and connectivity in rural communities. Journal of Transport Geography, 21, pp.102-112.

Vowles, T. M., 2006. Is the study of Transport repositioning Transport Geographers away from Geography? Journal of Transport Geography, 14 (3). 241-242

Wilson, M.W., 2013. Geospatial technologies in the location-aware future. Journal of Transport Geography. In press

Younger, M., Morrow-Almeida, H. R., Vindigni, S. M., \& Dannenberg, A. L., 2008. The built environment, climate change, and health: opportunities for co-benefits. American Journal of Preventive Medicine, 35(5), 517-26. doi:10.1016/j.amepre.2008.08.017

Zolnik, E.J., 2009. Context in human geography: a multilevel approach to study humanenvironment interactions, The Professional Geographer 61, 336-49. 